Tarih Kültür ve Sanat Araştırmaları Dergisi

Revue des Recherches en Histoire Culture et Art

مجلة البحوث التاريخية و الثقافية والفنية
Vol. 6, No. 2, March 2017

Copyright (c) Karabuk University

http://kutaksam.karabuk.edu.tr

\title{
DOI: 10.7596/taksad.v6i2.652
}

Citation: Rezaeian Koochi, M., Shavaki, G., \& Moradi, S. (2017). Analysis of Some Punishment Practices Based on Legal-Historical Principles of Iranian Society: Qajar Dynasty Case Study. Journal of History Culture and Art Research, 6(2), 647-654. doi:http://dx.doi.org/10.7596/taksad.v6i2.652

\section{Analysis of Some Punishment Practices Based on Legal-Historical Principles of Iranian Society: Qajar Dynasty Case Study}

\author{
Ghadir Najafzadeh Shavaki*1, \\ Mohammad Reza Rezaeian Koochi ${ }^{2}$ \\ Sajad Moradi ${ }^{3}$
}

\begin{abstract}
As one of their main functions to maintain political power, ruling dynasties in Iran always tried to establish social security and confront any events that might disrupt stability in the country. Therefore, various penalties had been meted out for perpetrators of such phenomena including social unrest, robbery, acting in disobedience to the orders of the Shah and other officials, disruption to economic activities and financial affairs of the people, murder, rape, drunken brawls in public places, and the like. These punishments were performed in various manners by non-religious jurisdictions or at the behest of the Shah, local rulers, or other security officials without any established procedures. Most of the punishments were based on the expediency of the government rather than the expediency of religion or jurisprudence. Rulers determined the manner of punishment on the basis of popular preferences. This type of conventional punishment, as opposed to legal or religious punishment, was quite common during the Qajar era, as a tool for countering the widespread social unrest. This has been reflected in the chronicles of many historians and in the diaries written by many European tourists visiting Iran during the period. The present study deals with various types of punishment of criminals and the manner of practicing such punishments during the Qajar era before the Constitutional Revolution. Findings of the study show that the punishments in the period were not based on any legal standards and that decisions of the Shah and other government officials determined the manner of performing punishments, often with much violence and harshness.
\end{abstract}

Keywords: Criminal responsibility, Ccrime, Punishment, Qajar, Law.

\footnotetext{
${ }^{1}$ Corresponder author: PhD candidate in History, Department of History, Kharazmi University, Tehran, Iran. E mail:najafzadehghadir@yahoo.com

${ }^{2} \mathrm{PhD}$ candidate in jurisprudence and criminal law, Department of Criminal Law and Criminology, Kharazmi University,Tehran, Iran. E mail: najafzadehghadir@yahoo.com

${ }^{3}$ MA student in History of Islam, Department of History, Kharazmi University, Tehran, Iran.
} 


\section{1-Introduction}

Crime is a social mistake, since most people are affected by committing a crime by the criminal (Mirmohammad Sadeghi, 2011: 3) and it has different meanings among criminologists, lawyers and sociologists. Although, it shouldn't be supposed that the only social response toward committing crimes, is to punish the criminals. As a result, it is worth to mention that when talking about punishment, we should consider the criminal justice system of different countries. We'd better keep in mind that one of the consequences of codification of criminal law is that each country will find its own way and change it into its own local and state law (Fletcher, 2005: 27).

Punishment laws in Iran also undergone drastic changes during history. The present study, tries to investigate the type of social responses to crimes during pre-constitutional revolution Qajar dynasty, based on the criminal justice principles according to the historical studies. During Qajar rule, and from the beginning, there wasn't any integrated system of justice in Iran, so the kings and their officials had the responsibility and the power to punish criminals as they wanted with no laws and civil rights available. There were two types of laws present at Qajar period in Iran: Sharia law that was based on Islamic rules and administered by religious rulers; and the ordinary or customary law that was administered by common judges in courts around the country (Karzan, 1994: 587/1; Polak, 1989: 226). In the following parts, we study the social-historical aspects of the punishments common in Qajar period.

\section{2-Penalty Typology in Qajar Period}

In typology of penalty, it is better firstly mention punishment system of Qajar era and then investigate the different types of punishments for crimes at that period.

\section{2-1-Sociological Foundations of Penalty System in Qajar Era}

Responsibility literally means being obliged to do things and in criminal dimension, it means "The offender being required to bear the outcome and punishment of his crime"; in other words, whoever commits a crime, is responsible against the victim and the society. Although until the crime is not proven by the judge, it is unfair to punish the convict. This is the case while in many situations, in different eras, punishments were unjust and sometimes unethical. In some historical periods, customary punishment by governors where so violent, cruel and far from humanity. These punishments were administered by the taste of the king or governors of the country, some of which are: exile, house arrest, running round the city and humiliate the convict, mutilation, beating, executing, burning, and throw from the height. Drouville counts three type of punishments for the convicts: 1-beating the feet; 2-amputation 
of ears and nose; and 3-executing (Drouville, 2010: 189). Other punishment is falak (smacking by rod). Iranians believe that smacking with rod is necessary to restore order. Robbers including the hooligans and brigands are punished by rod without considering any personal status. Malcolm mentions some customary sentences for the criminals such as: death penalty, whipping, beating, torture for confess about the stolen property location, eye gouging for those who claimed the throne, choking, drinking and killing, fragmentation of body parts, hanging the convict, continuously tortured to death, half the sentenced by tying the legs to two branches of a tree and throwing it, dip the sentenced in pit, etc. (Malcolm, 2004: 631632).

\section{2-2-Examples of Penalties in the Qajar Era}

\section{2-2-1-Execution (Deprivation of life)}

In a period of Qajar era, there were many behaviors been considered as crimes and opposite of the public order, so there were numerous types of punishments administered for them, one of which was to execute the convict. Montesquieu believes that: "there are two type of corruption in society: first, when people (the mass) do not obey the rules; this type is remediable; second, when the rules and laws make the mass corrupt, which doesn't have any treatment because the pain is resulted from the treatment itself" (Montesquieu, 1992: 200). In this era, Sharia had extended the criminalization that in turn, increased the number of punishments. Execution penalty sentenced for thieves, murderers, ravishment, great traitors, outlaws, and totally, the perpetrators of the heinous. Adulterous men were sentenced to death, and adulterous women were put in bags and being thrown into ditches (Drouville, 2010: 194).

For instance, once a woman who poisoned her husband, was sentenced to being put in a bag and thrown into ditch (Malcolm, 2004: 632). Execution or hanging or cutting head, was performed in public places. The corpse of the hanged man was divided into a few parts. One part on the gallows, one part on city gates (Polak, 1989: 227). In another case, for hanging, first they stuck a dirk into the chest of the convict and then, they cut his head and throw it out of the palace for edification and humiliation in the mud (Drouville, 2010:190).

Sometimes, the nose or ears of the offender were cut and they were wandering all over the markets that others take example. People were punished in the market and townships in the presence of people. Capital punishment and cutting head were done in Mohamadie square (definite capital punishment). At the center of this square, there was a big platform made of brick and a big beam was built on the board. This board and platform were used for capital punishment of offenders by Mirghazabs. Mostly, head of offenders were cut by Mirghazabs 
and their body was hanging by a string from the hanger above the beam and they were there for a long time that all people see them (Brugsch, 2010: 272).

Sometimes the convict was blinded before the execution. Then his hands, nose and ears were cut, then he was choked and finally he was hanged. For instance, once a robber was arrested and after being punished as mentioned above, his body was hanged for three days on the gallows (Bentham, 1975: 104). Or in another case, a convict sentenced to death was dipped into a pit while he was alive and his head was out of the pit. He was kept in this situation for a few days and he died after suffering a long time (Serena, 1983: 135). Sadeq khan Shaghaghi who wanted to occupy the throne, at the era of Fathalishah, was jailed in his own house and he couldn’t go out. He even ate his own hands and feet from hunger (Saravi, 1992: 192-193, 303-306; Etemad al-saltanah, 1988: 1450, 1415, 1413/3; Denbeli, 2004: 33-35; Shirazi, 2001: $55-60 / 1)$.

In 1800, Fathali who was angry because of Jafarkhan Bayat prevented from King's forces enter the Neyshaboor castle, commanded that Jafarkhan's son body was broken by beating and then his body organs were cut into pieces and his head and hands and feet were sent for his father (Denbeli, 2004: 50-51; Mahmoudmirza Qajar, 2010: 120-129).

\section{2-2-2-Amputation of Body Organs}

This is an Islamic concept: punishments which under Islamic law (Shariah) are mandated and fixed by God. These type of punishments were always controvertial in Islamic era and especially during Qajar period. One of these punishments is amputation of hand for robbery. Considering the punishment philosophy is one of the ways to overcome this problem of physical punishments. For example, for rubbery, there should be many factors for amputation, that for instance, in Kuwait Arabian conference on criminal behavior, in 1970, they claimed that there was no amputation in Saudi Arabia for more than twice a year and it was only 16 in 25 years.

As a result, it is essential to pay attention to the proportionality between crime and punishment in this kind of penalties. In polling experts about the possibility of cutting hands by surgery they answered: "although there is nothing about surgery in our religious books, it doesn't seem impossible". Another question about the problem is that does the thief can transplant his fingers after amputation or not? The answer is yes. (Mirmohamad Sadeghi, 1999: 289).

Way out of the dilemma is to provide a certain status for investigating the rules and coordination of the laws with the current situation of the society. It is worth to mention that 
amputation involved cutting fingers, cutting ears, cutting hands, cutting nose, blinding or piercing the eyes. Regarding those who commit small offences the punishment was as a chain was on his neck and they were behind the windows of the prison and people were seeing them. These people were poor and they were beginning to the passer by passing there and the prisoners didn't prevent them and they allowed them to beg freely and they took the begging money as their share from these prisoners (Brugsch, 2010: 273).

Severe punishment of chaining was done about those who committed bigger crimes. The offender was fastened to a wooden cross and a string was passing through the cross and its one end was attached to a hanger in the ceiling of Charsugh, cross was taken up to the ceiling of Charsugh and the prisoner was kept for a long time (Brugsch, 2010: 273).

\section{2-2-3-Falak or Smacking by Rod}

Other punishment is falak (smacking by rod). Iranians believe that smacking with rod is necessary to restore order. Robbers including the hooligans and brigands are punished by rod without considering any personal status. But Iranian people don’t know smacking by rod as their disrespect and their problem is only the pain of the rod. It was possible that by smacking, a person was disabled, paralyzed, fainting or even were dead.

Psychologically speaking, this type of abnormal punishments should be banned in the society (Shafiei Sarvestani, 2006: 107-110).

This punishment was performed for every public crime (stealing and banditry, murder, maim), political, military (escape from war, weakness against the enemy army, any type of mistake or military abuse), financial and official. "Although there were punishments such as cutting head or cutting hand, but most of the time, Falak or getting fined was common by the king to discipline the offenders" (Shil, 1989: 117; Karzan, 1994, 593/1). Falak was the lightest and at the same time among the most painful punishments. Method of beating the convict with Falak is described in tourists' diaries (Nag. Droville, 2010: 190; Shil, 1989: 216-217; Polak, 1989: 228). This type of punishment was very common at Qajar and contained all society levels including ordinary people, elites, and senior figures of the country, governors, and even prime ministers who became unpopular by the king. Sometimes Shah preferred these type of punishments and incompetent rulers were punished by Falak in front of the king. He punished the elite with different excuses (Shil, 1989: 216; Layard, 1997: 61).

Executioners collected a good money by Falak because they got sometimes money from the convict and then beat the smack lighter on the foot or used weak rods to be broken and finish earlier (Karzan, 1994: 594/1). In Shah's trips, they carried the Falak with them on mules (Orsel, 1973: 109). Sometimes, the convicts passed away during the Falak, or they crippled 
and didn't walk again, or they lost their nails or fingers (Layard, 1997: 61-62; Kotzobue, 1969: 135).

In Flanden report, there are parts about his clash with Iranians who were punished to be amplicated or whipped (Flandin, 1977: 95, 243-244). One of the bakers of James Mouriet was sentenced to Falak for stealing some money (Morier, 2007: 239). Brugsch has a report about a convict who was punished by Falak (Brugsch, 2010: 162). One of the other punishments was whipping with knotted ropes that resulted in breaking the convict's ribs (Kotzobue, 1969: 135). These violent actions was performed for edification of other people of the society.

\section{2-2-4-Prisoning}

Prison was one of the most important issues of the human rights during Qajar era because prison in statute book is a basic punishment that includes all small and big crimes but it is a secondary punishment in Islamic Sharia that is performed only for small and trivial crimes and the judge can do it or not (Waeli, 1983: 315).

Mrs. Serena mentions types of prisons in Naser-al-din Shah era. In Iran, in Qjar era, there were three types of prisons: private, Tehran ruler prison and Anbar Shahi prison. Most of the private prisons were in the house of wealthy people and it was made to punish their servants and slaves. Ruler prison was for the drunk, battery and robbery crimes but Anbar Shahi prison was for the criminals who attempted to kill he king and riot against the king (Serena, 1983: 132-133). In palace jail, prisoners were divided into 5-6 member groups and chained together. Sometimes one prisoners was tied lonely to a ring that was hanged on the wall. Prisons were dirty, wet places in which nothing found but chains, mosquitoes and fleas. The food was dried bread five times a day with a little water (Nazemoleslam, 2005: 346). Prisoners were tortured most of the time. Police chiefs and the rulers didn't have any special budget for feeding the prisoners and poor people were sentenced to die of hunger. Prisoners' expenses were supplied by themselves or charity (Nazemoleslam, 2005: 346; Serena, 1983: 132).

Based on the reports, sanitary conditions of the prisons were very bad and no action was done in order to improve the sanitary conditions of the prisons. Sometimes prisoners died of typhoid fever or other infectious diseases. Iran, it is common that at the end of year, some of the prisoners were released (Polak, 1989: 228).

Prison punishment has always been a controversial issue. "It is believed that prisoners may commit the crimes after being released from the prison and they may whipped or return to prison again" (Najafi Abrandabadi, 2002: 36-37). This is not a modern phenomenon and history has revealed that prison has always been dealing with numerous challenges. 


\section{2-2-5-Torture}

Torturing is a phenomena of dictatorship governments in which individual and honor of the human is not respected at all by the laws. However, it has undergone some tensions and some weaknesses during time (Adamiyat, 1983: 312). During Qajar era, torturing was a common punishment; that was performed for purposes such as confession of the accused, fleecing the rulers unpopular by the kings, or finding their properties hidden places (Polak, 1989: 228229), confession of the stealing properties (Malcolm, 2004: 631), gaining information from people. Tortures such as tying the hands to a tree so that body suspends in the air, burning armpit, putting the naked person on ice, closing the genital organ with the aim of blocking urethra. Serena claims that slavery and torture were still common during Qajar period. She believes that the officials do every violent action for punishing the convict that have performed even very small crimes (Serena, 1983: 133-136). Duirn ruling of Mohamad Shah Qajar, Prime Minister Haji Mirza Aghaqi exported a command for discarding the torture to which rulers didn't pay attention because the central government was not powerful enough to make them obey the commands. After him, Mirza Taghi Khan Amirkabir and Mirza Hossein Khan Sepahsalar had such commands that were performed only during their own power era (Adamiyat, 1983: 313).

\section{Conclusion}

The result of the present article is that social security was crucial for the continuation of political power of Qajar kings. One of the ways of security support, was to punish those who committed crimes but since there was not an efficient judiciary system and because of the weakness of the rules and laws, most punishments were so cruel and inhumane that didn't even have a Sharia or customary basics. This was a reason for rulers to abuse and make advantage or bribe during Qajar era. Most punishments were not performed for the convict to be disciplined, but it was for the Shah and rulers' satisfaction on their impulses.

\section{References}

Adamiyat, Fereydun (1983). Amir Kabir and Iran. Tehran: Kharazami.

Bentham, August (1975). August Bentan itinerary, translated by Mansoore nezam mafi etehadiye. Tehran: Sepehr press.

Brugsch, Heinrich (2010). A trip to Sultan Sahebgheran court 1859-1861, translated by Mohammadsaeed Kordbache. Tehran: Ettelaat.

Denbeli, Abd al-razzagh (2004). Maaser soltaniey, by Firooz Mansoori. Tehran: Etelaat. 
Drouville, Gaspard (2010). Drouville itinerary, translated by Javad Mohebbi. Qom: Niloofarane.

Flandin, Eugene (1977). Flandin Eugene itinerary to Iran, Translated by Hosein noorsadeghi. Tehran: Eshraghi.

Fletcher, George P. (2005). Concepts of criminal law, translated by Seyed Mehdi Seyedzadeh Sani. Mashhad: Razavi Islamic University.

Itemad al-Saltanah, Mohamadhassan Khan (1988). Naserid ordered history, corrected by Mohamad esmaeel Rezvani, vol.3. Tehran: Donyaye ketab.

Karzan, George Nathanil (1994). Iran and theorem of Iran, translated by Gholamali Vahid Mazandaranin, vol.1. Tehran: Scientific and cultural press.

Kotzobue, Moritz Von (1969). Trip to Iran, translated by Mahmoud Hedayat. Tehran: Amirkabir.

Layard, Austen Henry (1997). Layard itinerary and adventures in Iran 1840-1842, translated by Mehrab Amiri. Tehran: Anzan.

Mahmoud Mirza, Qajar (2010). Sahebgharani history, corrected by Nadere Jalali. Tehran: Library, meuseum, and documents center of the parliament.

Malcolm, Sir John (2004). Iran history, translated by Esmaeelmirza Heirat. Tehran: Sanayi.

Mir Mohammad Sadeghi, Hossein (1999). Criminal law: crimes against property, vol.2. Tehran: Mizzen press.

Mir Mohammad Sadeghi, Hossein (2011). Analysis of general principles of criminal law. Tehran: Jangal and Javedane.

Montesquieu, Charles (1992). The Spirit of the Laws, translated by Ali Akbar mahtadi. Tehran: Amirkabir.

Morier, James Jastinian (2007). Morier James itinerary, translated by Abolghasem Sari. Tehran: Toos.

Najafi Abrandabadi, Ali Hossein (2002). Investigation of alternatives for prison punishment, Law journal, No, 38, pp. 25-68.

Nazemoleslam Kermani, Mohamad ebne Ali (2005). Iranians awaken history, by Ali Akbar saidi sirjani. Tehran: Amirkabir.

Orsel, Ernest (1973). Orsel itinerary, translated by: Aliasghar Saeedi. Tehran: Zavar.

Polak, Jakob Eduard (1989). Polak itinerary, translated by Keikavoos Jahandari. Tehran: Kharazmi.

Saravi, Mohamad Fathollah (1992). Mohamadi history by Gholamreza tabatabaee Majd. Tehran: Amirkabir.

Serena, Carla (1983). Serena itinerary: People and Sights of Iran, translated by Ghlamreza Samii. Tehran: No Publication.

Shafiei Sarvestani, Ebrahim (2006). Injuries and legislative imperatives in the Islamic Republic of Iran. Qom: Islamic culture and science research center.

Shil, Lady Mary (1989). Diaries of Lady Shil, translated by Hosein Abootorabian. Tehran: No Publication.

Shirazi Khavari, Fazlollah (2001). Zolgharneyn history, corrected by: Naser Afshar far, vol. 1. Tehran: Islamic culture ministry, library, meuseum, and documents center of the parliament.

Waeli, Ahmad (1983). Prison laws in Islam, translated by Mohamad Hossein Bokaee, $2^{\text {nd }}$ ed. Islamic culture press. 